\title{
The System of Modern University Missions Realization in the Measurement of Three Key Components
}

\author{
Tetiana Bludova, Tetiana Halakhova, Larisa Hromozdova, Ganna Kashina, Tetiana Frolova
}

\begin{abstract}
Analysis of the choice of potential entrants' choice of Kyiv National Economic University named after Vadym Hetman (KNEU). We represent key influential factors of choosing KNEU named after Vadym Hetman by entrants: Motivational and Prestigious, Demographic, Geographical, Psychographic, Social. The article presents the key factors, hypotheses confirmation and segment identification of the applicants who choose university.

We build up the system of potential factors quantity of choosing KNEU by entrants on the basis of the above-mentioned hypotheses. This structured hierarchical scheme has 5 levels. Construction of the potential factors' magnitude of choosing KNEU by entrants.For building up the abovementioned potential factors quantity system of choosing KNEU by entrants it was realized the survey by questionnaire for each of the presented factors within KNEU annual survey of first-year students entitled "Motivational factors of university entrants before entering the university". The results of the survey, which was conducted in 2007, 2011 and 2017 for each item in all levels of the hierarchical scheme, were processed. In the three-dimensional Cartesian coordinate system, it was selected the axes are, which correspond respectively to the values of specific, relevant and potential factors for choosing $K N E U$ by entrants. We presented in geometric interpretation the potential of choosing KNEU by respondents in the form of rectangular parallelepipeds. The modern knowledge economy requires a modern system of proficiency competencies. That's why the most successful universities focus on instruments of higher education quality, realize educational programs' modernization on the base of student-centred education philosophy and build up a new system of the social network in the direction of social responsibility projects and business partnership with the academic community

Keywords: innovative, forward-looking education, stakeholder, social responsibility, segment identification, Motivational and
\end{abstract}

Revised Manuscript Received on December 30, 2019.

* Correspondence Author

Bludova Tetiana*, Advanced Mathematics Department, Kyiv National Economic University named after Vadym Hetman, Kyiv, Ukraine. Email: bltavl@ukr.net

Halakhova Tetiana, Department of International Management, Kyiv National Economic University named after Vadym Hetman, Ukraine. Email: tetyanagalakhova@gmail.com

Hromozdova Larisa, Department of Regional Studies and Tourism. Kyiv National Economic University named after Vadym Hetman, Kyiv, Ukraine. Email: Gromozdovag@gmail.com

Kashina Ganna, Department of Adult Education at the National Pedagogical University named after Drahomanov. Kyiv, Ukraine. Email: g.kashina@npu.edu.ua

Frolova Tetiana, Department of International Finance. Kyiv National Economic University named after Vadym Hetman, Kyiv, Ukraine. Email: frol_7@ukr.net

(C) The Authors. Published by Blue Eyes Intelligence Engineering and Sciences Publication (BEIESP). This is an open access article under the CC BY-NC-ND license (http://creativecommons.org/licenses/by-nc-nd/4.0/)
Prestigious factors, Relevant factors, potential factor, student-centred philosophy.

\section{INTRODUCTION}

The world has changed significantly. Nowadays, new technologies continuously arise and are implemented in different spheres of life in much more shorter time than the period of specialist qualification programs realization $[1,3,6$, $8,13]$. Thus, one of the main focus of modern education all around the world is the priority of innovative, outpacing, and forward-looking education $[2,16]$. In our perspective, the mission of the university in its classical definition as sense, a reason, boundaries of university activities cannot be imagined without two key basis features of people who are in this sphere: students, teachers, consultants, other stakeholders. In our mind, these two bases are mind power and spirituality $[4,20]$. We consider the mind power not only in the narrow sense, as rational cognition of personality, but in the broader sense, as an intellectual product of culture, as a force capable of understanding the system of modern knowledge and values. Additionally, the spirituality of abovementioned people can be understood as a system of cultural coordinates of life, moral aspects, creativity and tolerance $[2,12]$. In this context let's consider the university activities at the level of key stakeholders. They are applicants, students and future graduates [5]. The most well-known and successful universities continuously analyze the priorities of this stakeholders and orient its activities (curricula, university development strategies, etc.) to meet expectations of this group for building up sustaining relationships with them and creating a positive global image [15] . Nowadays, universities with proactive development policies tend not only to transfer modern knowledge, build up practical-oriented skills and understanding of entrepreneurial culture but also form a sense of social responsibility sense in terms of multicultural diversity $[3,7,21]$.

\section{THEORETICAL BACKGROUND}

\section{A. Key factors, hypotheses confirmation and segment identification of the entrants who choose KNEU named after Vadym Hetman}

Before focusing on the activities and perspectives of Kyiv National Economic University named after Vadym Hetman Advanced Mathematics Department, we will analyze potential entrants' choice of our university. 
Figure 1 presents key influential factors of choosing KNEU named after Vadym Hetman by entrants.

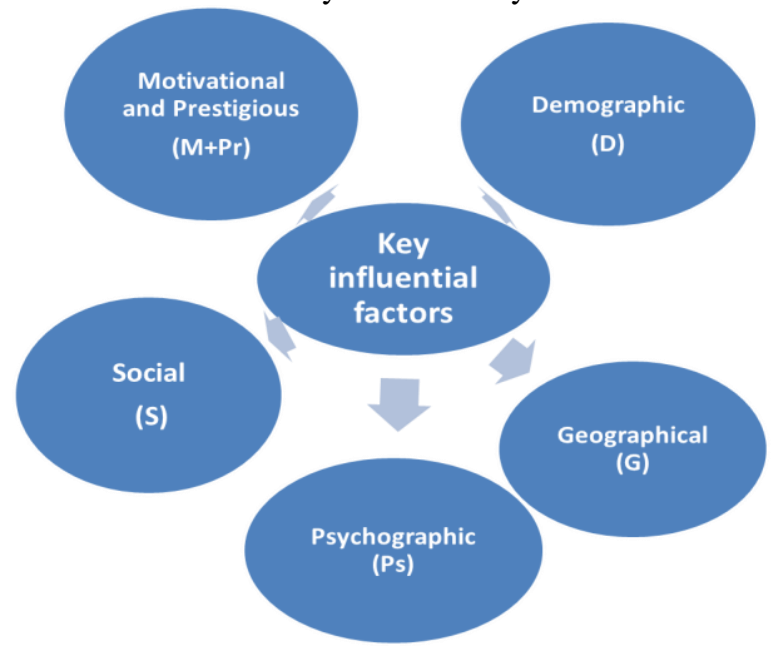

Fig.1. Key influential factors of choosing KNEU named after Vadym Hetman by entrants

Source: author's development on the basis of internal KNEU materials

And Table 1 illustrates the key factors, hypotheses confirmation and segment identification of the applicants who choose our university.

Table- I: Key factors, hypotheses confirmation and segment identification of the entrants who choose KNEU named after Vadym Hetman

\begin{tabular}{|c|c|c|}
\hline Factor & Hypothesis & $\begin{array}{l}\text { Entrants' segment } \\
\text { identification }\end{array}$ \\
\hline $\begin{array}{l}\text { Motivational } \\
\text { and } \\
\text { Prestigious } \\
(\mathrm{M}+\mathrm{Pr})\end{array}$ & $\begin{array}{l}\text { Motivation to get } \\
\text { high-quality } \\
\text { professional education. } \\
\text { Entrants choose } \\
\text { KNEU named after } \\
\text { Vadym Hetman } \\
\text { because the university } \\
\text { is well-known and } \\
\text { form a system of } \\
\text { modern professional } \\
\text { competencies. }\end{array}$ & $\begin{array}{l}\text { Applicants for whom it is } \\
\text { important to have the latest } \\
\text { education system. } \\
\text { KNEU named after Vadym } \\
\text { Hetman is one of Top } 10 \\
\text { Ukrainian Universities }\end{array}$ \\
\hline $\begin{array}{l}\text { Demographic } \\
\text { (D) }\end{array}$ & $\begin{array}{l}\text { Most entrants living in } \\
\text { families with average } \\
\text { monthly income is } \\
10,000-15,000 \mathrm{UAH} \text {. }\end{array}$ & $\begin{array}{l}\text { Nationality: Almost all of the } \\
\text { entrants are Ukrainians. } \\
\text { Gender: On average half of } \\
\text { entrants are boys and half are } \\
\text { girls. } \\
\text { Age: } 17-18 \text { years old. } \\
\text { Family members: Almost all } \\
\text { of the entrants are living in } \\
\text { families with } 3-4 \text { people. At } \\
\text { the same time, the largest } \\
\text { number of entrants who select } \\
\text { our university come from a } \\
\text { family of } 3 \text { people. }\end{array}$ \\
\hline $\begin{array}{c}\text { Geographical } \\
\text { (G) }\end{array}$ & $\begin{array}{l}\text { Mainly entrants come } \\
\text { from Kiev }\end{array}$ & $\begin{array}{l}\text { The hypothesis is confirmed: } \\
\text { it is possible to allocate the } \\
\text { segment of entrants from Kiev } \\
\text { (separate students after Kiev } \\
\text { colleges). }\end{array}$ \\
\hline $\begin{array}{l}\text { Psychographic } \\
\text { (Ps) }\end{array}$ & $\begin{array}{l}\text { Entrants who strive to } \\
\text { solve professional } \\
\text { issues effectively }\end{array}$ & $\begin{array}{l}\text { The segment of entrants, who } \\
\text { are mainly extraverts and } \\
\text { believe that they are erudite, } \\
\text { interesting and knowledgeable } \\
\text { in life affairs. }\end{array}$ \\
\hline $\begin{array}{l}\text { Social } \\
\text { (S) }\end{array}$ & $\begin{array}{l}\text { Entrants come from } \\
\text { families of employees } \\
\text { whor perceive } \\
\text { information }\end{array}$ & $\begin{array}{l}\text { A definite segment of entrants } \\
\text { belongs to the class of people } \\
\text { of average prosperity level, i.e. } \\
\text { employees }\end{array}$ \\
\hline
\end{tabular}

\section{B. The system of potential factors quantity of choosing KNEU by entrants}

We build up the system of potential factors quantity of choosing KNEU by entrants on the basis of the above-mentioned hypotheses (Fig.2).

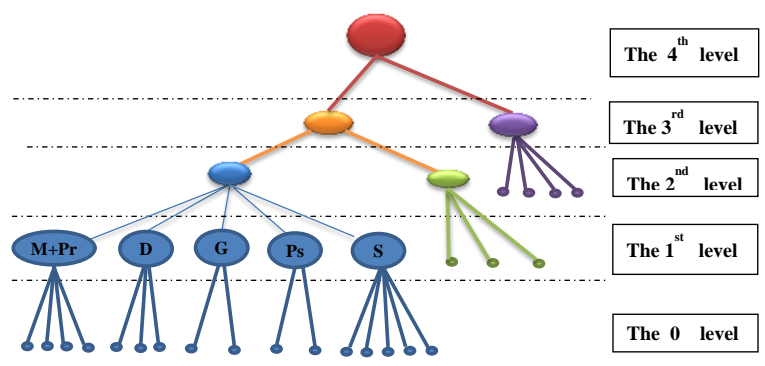

Fig.2. The system of potential factors quantity of choosing KNEU by entrants

Source: author's development on the basis of data presented in Table 1

The found weights are presented in Tables 2,3,4. Numbers in parentheses indicate the weights which found for each key aspects of the factor.

Table- II: Key factors, basic scheme and weights (the 0 level of aggregate specific factors of entrants)

\begin{tabular}{|l|l|l|}
\hline \multicolumn{1}{|c|}{ Factor } & Weights \\
\hline $\begin{array}{l}\text { Motivational } \\
\text { Prestigious } \\
\text { factors of } \\
\text { entrants }\end{array}$ & \\
\hline $\begin{array}{l}\text { Demographic } \\
\text { factors of } \\
\text { entrants }\end{array}$ & \\
\hline $\begin{array}{l}\text { Geographical } \\
\text { factors } \\
\text { entrants }\end{array}$
\end{tabular}

Source: author's development on the basis of data presented in Table 1

This structured hierarchical scheme has 5 levels (Fig 1). Having used the method of inverse symmetric matrices and taken into account the theory of eigenvalues, we found the factors weight coefficients for certain groups of indices of each level. 
Such matrices are determined by the experts' group due to a pairwise expert comparison of factors in a group using 5-point assessment scale. There was determined the uncertainties of expert matrices compiling with the help of the random matrices method. Note that the group of experts included professors of the Mathematical and Sociological departments.

For Motivational and Prestigious factors of entrants we identified the following key factors such as:

- the persistence in the university choosing process,

- the reasons and the degree of readiness to enter the university,

- expected personal benefits,

- the attitude toward the university educational format.

The key sub-factors for entrants Demographic group of factors are the following:

- stage of entrants' personal and professional level,

- the average monthly income of the family,

- the level of general secondary education.

The key sub-factors for entrants Geographical factors are the following:

- University choice based on geographic distances aspects,

- the level of students enrolment of the university.

The key aspects of the psychographic factor are:

- identifying the psychological type of entrants,

- entrants' self-assessment of psychological qualities.

The key aspects of the Social factor are

- social status,

- the occupation type,

- exclusive behavior,

- life value-oriented approach,

- perception and analysis of information.

Thus we completed this scheme by zero level and summarized it. (Table 3).

Table- III: Name of the Table that justify the values

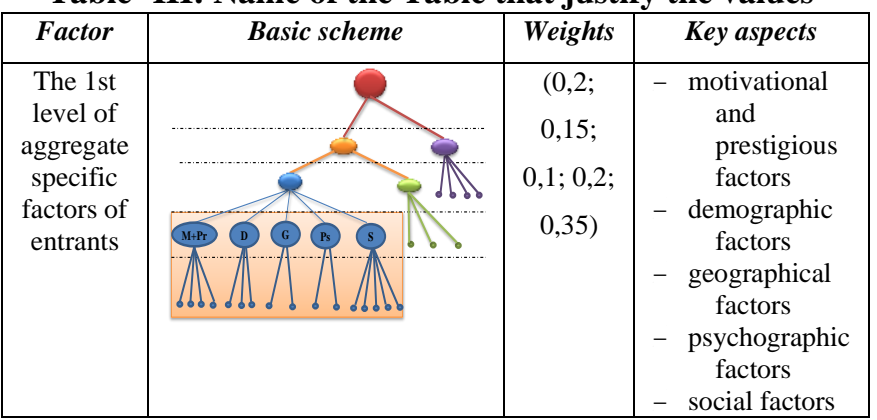

Source: author's development on the basis of data presented in Table 1

As can be seen from the table 3 the 1 st level of aggregate specific factors of entrants has the following weights $(0,2$; $0,15 ; 0,1 ; 0,2 ; 0,35)$. The greatest weight has the social factor (the weight of the social factor equals 0,35 ). It is worth emphasizing that two factors in the scheme have equal weights. These factors are the following: the first group is motivational and prestigious. And the second one is psychographic. Their weights equal 0,2. Further important are The demographic and geographical factors groups have the smallest values which are 0,15 and 0,1 respectively.
Then we found weight coefficients for Determinants of entrants. The key aspects of this factor are:

- the identification of university entrants in certain areas,

- University choice,

- characteristic of the chosen university.

Then we find the 2nd level of aggregate specific factors of entrants that include:

- aggregate specific factors,

- determinants.

Table 4 is presented the 2nd level of aggregate specific factors of entrants.

Table- IV: Construction of the potential factors' magnitude of choosing KNEU by entrants (the 2nd level of aggregate specific factors of entrants)

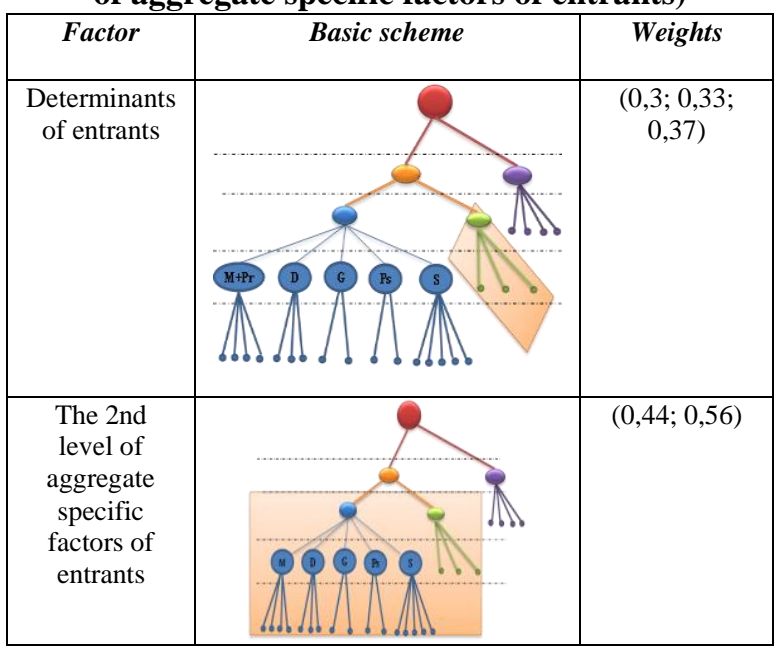

Source: author's development on the basis of data presented in Table 1

We proceed to the next level of the hierarchy and consider the relevant factors of entrants (Table 5).

Table- V: Element of the 2nd level: Relevant factors of entrants

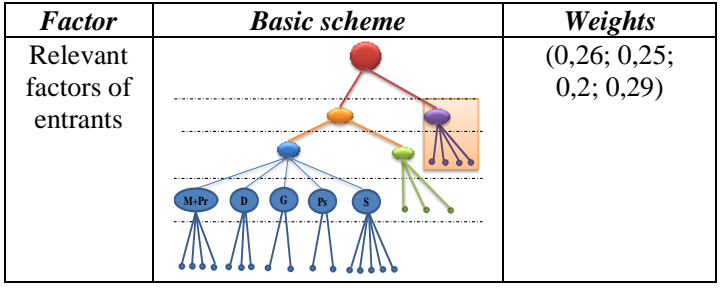

Source: author's development on the basis of data presented in Table 1

The key aspects of this factor are:

- the University's price offers,

- University's benefits in the educational services market of Ukrainian universities,

- University's benefits in the educational services market of foreign universities,

- university different offers by faculty.

The next Table 6 is presented the 3rd and the 4th levels of aggregate specific factors of entrants.

Published By: 
Table- VI: Construction of the potential factors' magnitude of choosing KNEU by entrants (the 3rd and the 4th level of aggregate specific factors of entrants)

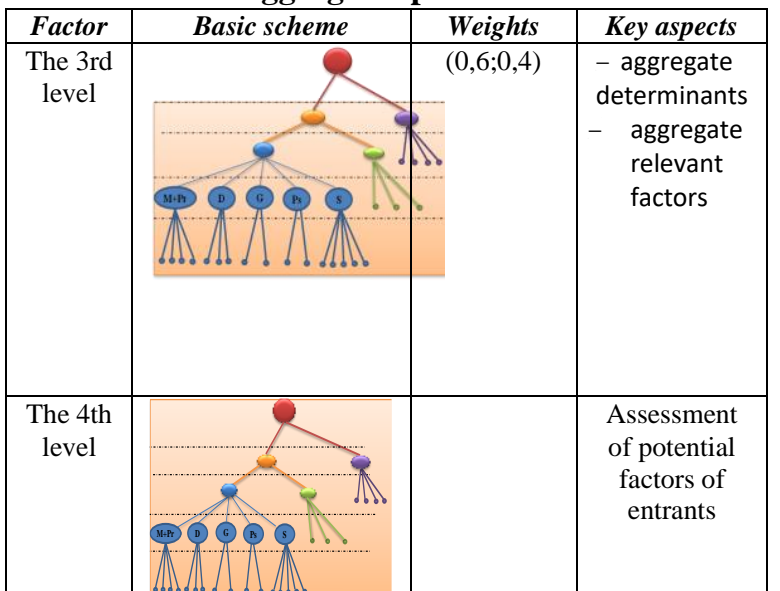

Source: author's development on the basis of the data presented in Table 1

As can be seen from Table 6 weights of aggregate determinants and aggregate relevant factors are equal 0,6; 0,4 respectively. The highest level of hierarchy is the fourth level which evaluates the potential factors of entrants.

\section{RESULTS}

For building up the abovementioned system of potential factors quantity of choosing KNEU by entrants it was realized the survey by questionnaire for each of the presented factors within KNEU annual survey of first-year students [10].

It is worth noting that KNEU conducts an annual survey of first-year students entitled "Motivational factors of university entrants before entering the university".

According to the results of the abovementioned survey which was conducted in 2007, 2011 and 2017 years for each item of all levels of the presented hierarchy scheme, it was found the sample mean values. Assuming that the results of measurements are distributed normally, it was made the estimations of actual values of the measured quantities using large sample confidence intervals with reliability.

Table VII - IX presents the Average sample point scores for the $1^{\text {st }}, 2^{\text {nd }}, 3^{\text {rd }}$ levels of potential factors quantity of choosing KNEU by entrants.

We would like to emphasize that the survey was conducted in two periods: 1 January-30 June and 1 July - 31 December for the three years 2007, 2011, 2017 respectively.

Table VII presents the Average sample point scores for the $1^{\text {st }}$ level of aggregate specific factors of entrants for the specified periods taking into account the weighting factors

Table- VII: The Average sample point scores for the 1st level of aggregate specific factors

\begin{tabular}{|c|c|c|c|c|c|c|}
\hline \multirow{3}{*}{$\begin{array}{c}\text { Weighting } \\
\text { factors }(0,2 ; \\
0,15 ; 0,1 ; 0,2 ; \\
0,35) \\
\text { Elements of } \\
\text { the first level } \\
\text { of the } \\
\text { hierarchy }\end{array}$} & \multicolumn{6}{|c|}{$\begin{array}{c}\text { Average sample point scores } \\
\text { The 1st level of aggregate specific factors of entrants }\end{array}$} \\
\hline & \multicolumn{2}{|c|}{2007} & \multicolumn{2}{|c|}{2011} & \multicolumn{2}{|c|}{2017} \\
\hline & $\begin{array}{l}1.01 \\
-30.06\end{array}$ & $\begin{array}{l}1.07- \\
31.12\end{array}$ & $\begin{array}{l}1.01 \\
-30.06\end{array}$ & $\begin{array}{l}1.07 \\
-31.12\end{array}$ & $\begin{array}{l}1.01 \\
-30.06\end{array}$ & $\begin{array}{l}1.07- \\
31.12\end{array}$ \\
\hline $\begin{array}{l}\text { motivational } \\
\text { and } \\
\text { prestigious }\end{array}$ & 4,63 & 4,71 & 3,27 & 3,55 & 4,32 & 4,35 \\
\hline
\end{tabular}

\begin{tabular}{|l|c|c|c|c|c|c|}
\hline factors & & & & & & \\
\hline $\begin{array}{l}\text { demographic } \\
\text { factors }\end{array}$ & 5,37 & 4,66 & 4,37 & 4,61 & 2,63 & 3,48 \\
\hline $\begin{array}{l}\text { geographical } \\
\text { factors }\end{array}$ & 4,62 & 4,72 & 3,23 & 3,51 & 4,02 & 4,25 \\
\hline $\begin{array}{l}\text { psychographic } \\
\text { factors }\end{array}$ & 5,56 & 4,71 & 4,53 & 4,28 & 2,64 & 3,47 \\
\hline social factors & 8,41 & 7,48 & 6,33 & 6,67 & 5,15 & 5,24 \\
\hline $\begin{array}{l}\text { Weighted } \\
\text { average }\end{array}$ & 5,841 & 5,339 & 4,431 & 4,598 & 3,805 & 4,155 \\
\hline
\end{tabular}

Source: author's calculations

Table VIII presents the Average sample point scores for the 2nd level Construction of the potential factors of entrants.

Table- VIII: The Average sample point scores for the 2nd level Construction of the potential factors of entrants

\begin{tabular}{|c|c|c|c|c|c|c|}
\hline $\begin{array}{c}\text { Weighting } \\
\text { factors } \\
(0,44 ;\end{array}$ & \multicolumn{5}{|c|}{$\begin{array}{c}\text { Average sample point scores } \\
\text { The 2nd level Construction of the potential factors of } \\
\text { entrants }\end{array}$} \\
\cline { 2 - 7 } $\begin{array}{c}\text { Elements } \\
\text { of the } \\
\text { second } \\
\text { level of } \\
\text { the } \\
\text { hierarchy }\end{array}$ & \multicolumn{2}{|c|}{2007} & \multicolumn{2}{|c|}{2011} & \multicolumn{2}{c|}{2017} \\
\cline { 2 - 7 } & -30.06 & $\begin{array}{l}1.07- \\
31.12\end{array}$ & $\begin{array}{l}1.01- \\
30.06\end{array}$ & $\begin{array}{l}1.07 \\
-31.12\end{array}$ & $\begin{array}{l}1.01 \\
-30.06\end{array}$ & $\begin{array}{l}1.07- \\
31.12\end{array}$ \\
\hline $\begin{array}{c}\text { specific } \\
\text { factors of } \\
\text { entrants }\end{array}$ & 5,25 & 4,34 & 4,6 & 4,77 & 2,78 & 3,32 \\
\hline $\begin{array}{c}\text { potential } \\
\text { factors of } \\
\text { entrants }\end{array}$ & 8,32 & 8,44 & 7,66 & 7,73 & 6,52 & 7,23 \\
\hline $\begin{array}{l}\text { Weighted } \\
\text { average }\end{array}$ & 6,6008 & 6,144 & 5,9464 & 6,0724 & 4,4256 & 5,0404 \\
\hline
\end{tabular}

Source: author's calculations

Table IX presents the Average sample point scores for the 3rd level of aggregate specific factors of entrants.

Table- IX: The Average sample point scores for the $3^{\text {rd }}$ level of aggregate specific factors of entrants.

\begin{tabular}{|l|c|c|c|c|c|c|}
\hline $\begin{array}{l}\text { Weighting } \\
\text { factors } \\
(0,6 ; 0,4)\end{array}$ & \multicolumn{5}{|c|}{$\begin{array}{c}\text { Average sample point scores } \\
\text { The 3rd level Construction of the potential factors of } \\
\text { entrants }\end{array}$} \\
\cline { 2 - 7 } $\begin{array}{l}\text { Elements of } \\
\text { the 3rd level } \\
\text { of the } \\
\text { hierarchy }\end{array}$ & $\begin{array}{c}|c| \\
2007\end{array}$ & \multicolumn{2}{|c|}{2011} & \multicolumn{2}{c|}{2017} \\
\cline { 2 - 7 } & -30.06 & 31.12 & 30.06 & 31.12 & -30.06 & $\begin{array}{c}1.07- \\
31.12\end{array}$ \\
\hline $\begin{array}{l}\text { aggregate } \\
\text { determinants }\end{array}$ & 8,32 & 8,41 & 7,89 & 7,93 & 6,82 & 7,21 \\
\hline $\begin{array}{l}\text { aggregate } \\
\text { relevant } \\
\text { factors }\end{array}$ & 8,56 & 8,63 & 7,21 & 7,43 & 6,22 & 7,43 \\
\hline $\begin{array}{l}\text { Weighted } \\
\text { average }\end{array}$ & 8,4448 & 8,5244 & 7,5364 & 7,67 & 6,508 & 7,3244 \\
\hline
\end{tabular}

Source: author's calculations

In the three-dimensional Cartesian coordinate system, the axes are selected, which correspond respectively to the values of specific, relevant and potential factors for choosing KNEU by entrants. We presented in geometric interpretation the potential of choosing KNEU by respondents in the form of rectangular parallelepipeds. Their edges are confidence intervals of specific, relevant and potential factors for choosing KNEU by entrants (Fig 3). 


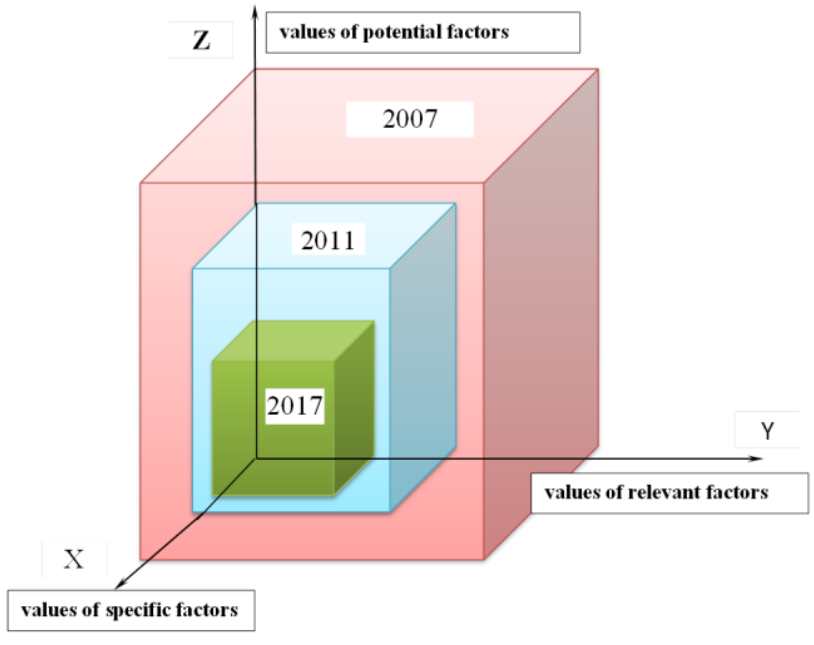

Fig.3. The illustration of the magnitude of the available potential factor of entrants who are choosing KNEU for the period of 2000-2017 years

Source: author's development on the basis of the data presented in Table 1

In 2017, the representative sample of the survey covers 1175 respondents. Among different questions, the basic question was "Do you think it is necessary to receive higher education in Ukraine?" It should be noted that $62.7 \%$ of respondents noted a significant necessity of higher education in Ukraine (Fig.4).

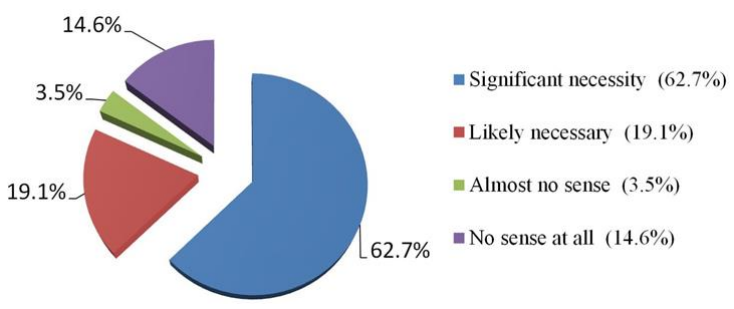

Fig. 4. The distribution of respondents' answers to the necessity of higher education in Ukraine in 2017 year (in $\%)$

Source: KNEU's internal materials: student survey results in 2017. The survey was realized by the Department of Informatics and Systemsology and the Department of Sociology

For further analysis, it is worth noting that among other influential factors the demographic factor plays one of the key roles in the university entrance as shown in the Figure 5.

In Ukraine, the number of applicants falls down due to the demographic crisis from year to year. There is a decrease in the number of school graduates up to 2019 due to demographic problems. According to the State Statistics Service of Ukraine, from 2005 to 2018 year, the number of entrants dropped from 526 thousand to 203 thousand people. Taking into account abovementioned information the competition for entrants between Ukrainian universities has been increasing for the last 12 years. This fact enforces universities to improve continuously their educational, scientific and social activities. In such context, social responsibility direction of universities improvement strategy is a new but very important aspect in the realities of Ukraine.
Fig. 5. Number of births in thousand (in parentheses it is indicated the potential year of university entrance)

Source: author's development on the basis of the State Statistics Service of Ukraine data

\section{SOCIAL MISSION REALIZATION}

In this context, we would like to highlight the efforts of the Advanced Mathematics Department, from the perspective of university social mission (Figure 6). Questions of social mission are widely represented in the scientific literature [1, 17, 23].

Under these conditions the collective of the department carries out in full the social mission of the university (Figure $6)$ :

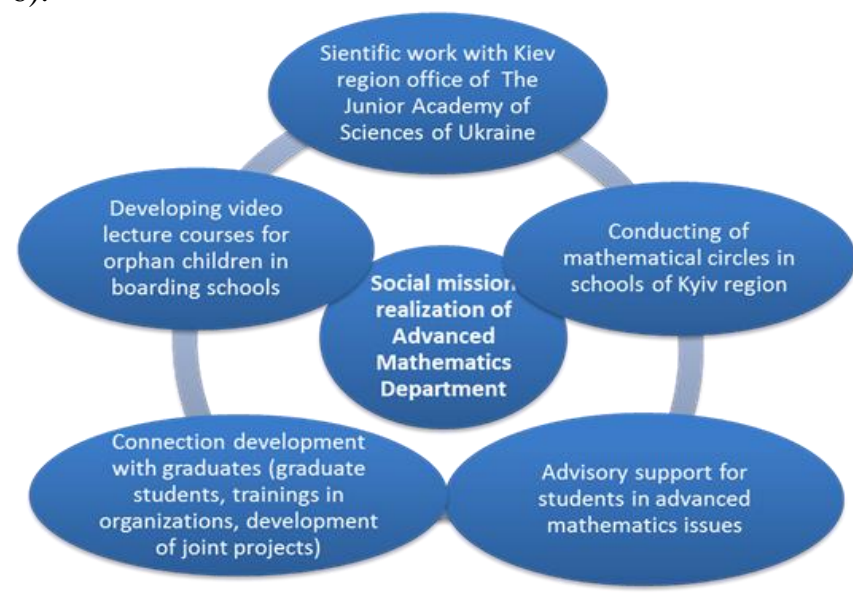

Fig.6. Social mission realization of Advanced Mathematics Department

Source: internal materials of Advanced Mathematics Department, KNEU

- In 2017, it was made the video-course of 30 lectures on elementary mathematics for preparation to external independent test evaluation. It was distributed to boarding schools for orphan children who are not capable of full-time training.

- Teachers of the department conduct mathematical circles in schools of Kyiv region, spending a lot effort to interest children in mathematics and the further orientation of entering KNEU. 
- Teachers of the department work fruitfully with the Kiev region office of The Junior Academy of Sciences of Ukraine in the aspect of applied mathematics. Four teachers of the department select the best works and help the best children to improve their work for taking part in the All-Ukrainian competition.

A lot of students choose the speciality programmes recommended by our teachers and continue working fruitfully within the university. We pay attention of our students that they could contact and get the support from Advanced Mathematics Department towards their professional issues concerning mathematical and statistical processing of data. And as a response from such social work, our graduate invited teachers from Advanced Mathematics Department to develop and conduct a training course on mathematical and statistical processing of data for the employees of his business organization [22].

The teachers of department always are invited to the annual meetings of KNEU graduates. This is also an indicator of the development of social networks and activities.

\section{THE SYSTEM OF MODERN UNIVERSITY MISSIONS}

In this context, a number of priority issues concerning the modernization of higher education are considered:

- establishing a student-centred approach to the educational process;

- adapting educational activities, vector to the challenges of modern business realities and training competitive professionals who capable of quickly responding to changes in the socio-economic environment.

- creating institutional foundations for ensuring clarity and comparability of learning outcomes, competencies and acquired qualifications;

The establishment of a new educational activity paradigm and the creation of an objective, transparent and flexible system of higher education quality assurance is based on the following principles:

- establishing a student-centred approach to the educational process;

- increasing of the leadership potential of the economic university,

introducing the consolidated liability of universities and business structures

The student-centred mission is a base of other modern university missions (Figure 7).

Student-centred philosophy of the university education development system based on the following principles:

- providing active participation of students in the scientific and educational processes;

- forming students' individual educational trajectories and, accordingly, an individual profile of competencies;

- realizing educational programs in concordance with the development of the knowledge economy, on the whole, and changes of domestic and international labour markets, in particular.

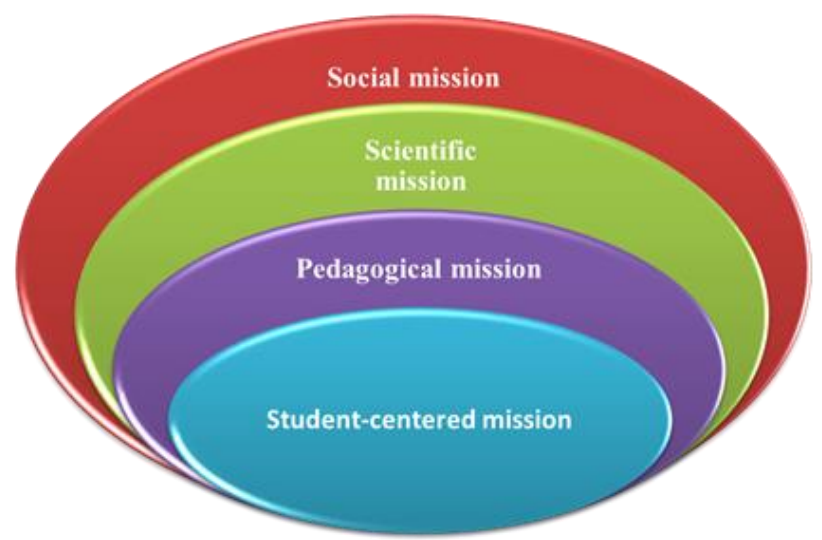

Fig.7. The system of modern university missions

Source: author's development

In our opinion, student-centred learning is a key vector of improving the quality of the higher education system and gaining a competitive advantage by graduates.

\section{UNIVERSITY'S SOCIAL MISSION REALIZATION IN THE MEASUREMENT OF THREE KEY COMPONENTS}

Note that the educational process in the KNEU named after Vadym Hetman oriented on the preferences and interests of students, has always dominated within the walls of our university [26, 27].

It is worth noticing that student-centred mission is an integral part of the Bologna Initiatives. KNEU named after Vadym Hetman was one of the first university in Ukraine which introduced educational process according to individual plans, realized the possibility of individual trajectories of training; got a system of double diplomas. Furthermore, it has realized competence-oriented approach to the educational process and in this area, we have many considerable achievements (Figure 8).

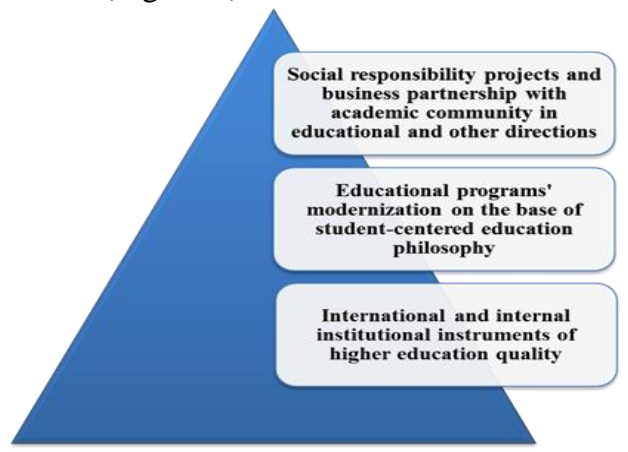

Fig. 8. University's social mission realization in the measurement of three key components

Source: author's development

It is worth noting that the global economy and post-industrial society produce new quality requirements for educational services and universities activities. The modern knowledge economy requires a modern system of proficiency competencies (in particular, they are: teamwork skills, lifelong learning, readiness to change, ability to act in non-standard situations, etc) $[18,19]$. 
That's why the most successful universities focus on instruments of higher education quality (up-to-date international and internal standards, plans, etc), realize educational programs' modernization on the base of student-centered education philosophy and build up a new system of social network in the direction of social responsibility projects and business partnership with academic community.

\section{RESULT AND DISCUSSION}

1) The modern socio-economic development requires an innovative framework of universities activity not only in the direction of scientific and pedagogical activity but also in the direction of active social activity. Ukraine universities in contrast to European ones only now start understanding the value of social mission.

2) In conclusion, we would like to give an example of an outstanding German composer and pianist Ludwig van Beethoven. In our opinion, his only one opera "Fidelio" is a world masterpiece which has an absolutely innovative format.

3) The opera embodies the leading idea of Beethoven works: suffering is overcome in the stubborn heroic struggle, which leads to the liberation. In this context, we support the idea of a harmonious combination of all university missions and overcoming the psychological obstacles connected with undervaluing the third mission.

4) Thus, we cannot consider the social mission of the university separately, but only in its multifunctional combination and development with the educational and pedagogical missions $[9,11,14]$. Nowadays this combination is very important for university activity because society entrusts the university to educate a prominent stratum of youth for future effective development of the state.

\section{CONCLUSION}

The efforts of the Advanced Mathematics Department, from the perspective of university social mission are presented. The establishment of a new educational activity paradigm and the creation of an objective, transparent and flexible system of higher education quality assurance is based on the following principles: establishing a student-centred approach to the educational process; increasing of the leadership potential of the economic university; introducing the consolidated liability of universities and business structures.

We build up the system of potential factors quantity of choosing KNEU by entrants on the basis of the above-mentioned hypotheses. This structured hierarchical scheme has 5 levels. Construction of the potential factors' magnitude of choosing KNEU by entrants (the 1st level of aggregate influential factors of choosing KNEU, the 2nd level of aggregate specific factors of entrants, the 3rd level of aggregate specific factors of entrants, the 4th - assessment of potential factors of entrants).For building up the abovementioned potential factors quantity system of choosing KNEU by entrants it was realized the survey by questionnaire for each of the presented factors within KNEU annual survey of first-year students entitled "Motivational factors of university entrants before entering the university". The modern knowledge economy requires a modern system of proficiency competencies. That's why the most successful universities focus on instruments of higher education quality, realize educational programs' modernization on the base of student-centred education philosophy and build up a new system of the social network in the direction of social responsibility projects and business partnership with the academic community.

\section{REFERENCES}

1. Alger, V. E., "Teacher Incentive Pay that Works: A Global Survey of Programs that Improve Student Achievement, Vancouver: Fraser Institute

2. Alger, V. E., 2014: Teacher Incentive Pay that Works: A Global Survey of Programs that Improve Student Achievement. Vancouver: Fraser Institute.

3. Arthur, J. \& Bohlin, K. E. (Eds.). Citizenship and Higher Education: The Role of Universities in Communities and Society. Oxon: RoutledgeFalmer. 2005.

4. Barnes, M. E. The Student as Teacher Educator in Service-Learning Journal of Experiential Education, 2016, 39, 3, 238-253.

5. Bennett, D., Sunderland, N., Bartleet, B.-L. \& Power, A. Implementing and sustaining higher education service-learning initiatives: Revisiting Young et al.'s organizational tactics. Journal of Experiential Education, 2016, 39, 2, 145-163.

6. Brail, S. Quantifying the value of service-learning: a comparison of grade achievement between service-learning and non-service-learning students. International Journal of Teaching and Learning in Higher Education, 2016, 28, 2, 148-153.

7. Cobban Allan B. The Medieval Universities: their Development and Organization. London : Methuen, 1975, 264 p.

8. Dima G. (Coord.) et al. University Social Responsibility: A Common European Reference Framework. Final Public Report of the EU-USR Project 2015 (pp. 10-13). [Available in English, Portuguese, Spanish, French and Romanian. http://www.eu-usr.eu/?p=607].

9. Geuna Aldo . The Economics of Knowledge Production. Funding and the Structure of University Research. Edward Elgar, 1999, 206 p.

10. Glewwe, P. - Ilias, N. - KREMER, M. Teacher Incentives. American Economic Journal: Applied Economics, 2010Vol. 2, No. 3, pp. 205-227.

11. Gorbunova L. Key Competencies in Transnational Educational Space: the Definition and Implementation / Філософія освіти. Philosophy of Education. 2016. №2(19). - P. 97-117 [In Ukrainian]. URL: www.philosopheducation.com

12. Horta H., "Global and National Prominent Universities: Internationalization, Competitiveness and the Role of the State," High Educ, 58. 2009- p. 387-405.

13. McIlrath, L., Lyons, A. \& Munck, R. (Eds.) Higher Education and Civic Engagement: Comparative Perspectives. New York: Palgrave Macmillan. 2012

14. Munck, R., Kelly, U. \& Ozarowska, J. ,"The value of civic engagement in higher education: An Irish case study, " DCU in the community papers no. $1 . \quad 2015$ https://www.dcu.ie/sites/default/files/community/pdfs/Value.pdf

15. Newman J. H. C. The idea of the university: defined and illustrated /J. H. C. Newman. - San Francisco.1960. - 430 p.

16. Anchez-Ramos, D., Sánchez-Emeterio, G., De la Hoz, E., Pérez-de-Los-Reyes, C., Rodriguez-Benitez,L. \& Garrido, I. "Educational potential of development cooperation: a university-NGO 36 Guidelines for Universities Engaging in Social Responsibility collaborative experience, " INTED 2016. Proceedings: 10th International Technology, Education and Development Conference. Valencia: IATED. 2271-2278.

17. Scott, J. C., "The Mission of the University: Medieval to Postmodern Transformations , " The Journal of Higher Education. 2006. Vol. 77, No 1 (January/ February), pp. 1-39.

18. Scott, John C. The Mission of the University: Medieval to Postmodern Transformations // The Journal of Higher Education, 2006. Vol. 77, № 1, Special Issue: Moving into the Next 75 Years. - p. 1-39. 
19. Slater, H. - Wilson, D., "Evaluating the Impact of Performance-Related Pay for Teachers in England. Labour Economics, " 2009, Vol. 16, pp. 251-261.

20. Tirivayi, N. - Van den Brink, H. - Groot, W., "Group Incentives for Teachers and their Effects on Student Learning: a Systematic Review of Theory and Evidence," School Effectiveness and School Improvement, 2014.Vol. 25, No. 4, pp. 570- 601.

21. Traver, A. E. \& Katz, Z. P. (Eds.), "Service-Learning at the American Community College: Theoretical and Empirical Perspectives, " New York: Palgrave Macmillan. 2014.

22. Veysey Laurence R. The emergence of the American University. The University of Chicago Press, 1965, 505 p.

23. Vidal, I. Reflexión sobre la responsabilidad social universitaria. 2013DOI:10.13140/RG.2.1.4422.6009

24. Weber M., "Science as a Vocation / Translated from German. Selected: Protestant Ethics and the Spirit of Capitalism," 2nd edition. M.: ROSSPEN, 2006, pp. 529-548 [In Russian].

25. Woessmann, L. Cross-Country Evidence on Teacher Performance Pay. Economics of Education Review, 2011, Vol. 30, No. 3, pp. 404-418.

26. Bludova T.V. Formation of competences in the study of basic mathematical disciplines on the basis of student-centered approach / TV Bludova, OV Magda // Student-centrism in the system of quality assurance of education in the economic university: Coll. materials All-Ukrainian. scientific-method. Conf. for the international Participation, (Kyiv, March 2-3, 2016) / Ministry of Education and Science of Ukraine, State Higher Educational Institution "Kyiv. nat econom. them. Hetman "; editors: AM Kolot, TV Gut. - Kiev: KNEU, 2016. - P. 149. http://ir.kneu.edu.ua:8080/handle/2010/17759

27. Bludova T.V. A new look at the content of the program of higher mathematics for economists from the standpoint of student-centered approach / TV Bludova, NP Shchekan // Student-centrism in the system of quality assurance of education in the economic university: Coll. materials All-Ukrainian. scientific-method. Conf. for the international Participation, (Kyiv, March 2-3, 2016) / Ministry of Education and Science of Ukraine, State Higher Educational Institution "Kyiv. nat. econom. them. Hetman "; editors: AM Kolot, TV Gut. - Kyiv: KNEU, 2016. - P. 302-303.http: //ir.kneu.edu.ua: 8080 / handle / 2010/18030

\section{AUTHORS PROFILE}

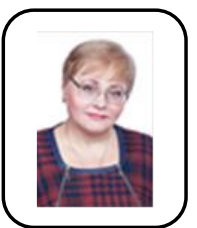

Bludova Tetiana, Doctor of Economics (Ph. D., D.S), Professor, Head of the Advanced Mathematics Department, Marketing Faculty, Kyiv National Economic University named after Vadym Hetman, Kyiv, Ukraine Tetiana Bludova delivers the following courses: Advanced Mathematics, Probability Theory and Mathematical Statistics, Mathematical Support in Economics. She is the author of 137 scientific publications. The main directions of Tetiana Bludova scientific activity are: models of economic security of the state and economic-mathematical modeling in the field of business economics, marketing, financial and banking activities.

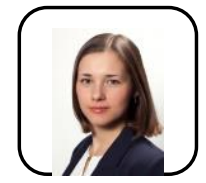

Halakhova Tetiana, Candidate of Economic Sciences, Associate Professor, Department of International Management, Kyiv National Economic University named after Vadym Hetman, Ukraine.

Education: Kyiv National Economic University named after Vadym Hetma. Research topics: Innovative and creative format of the international management system. Creative component in international company management. The main directions of Galakhova Tetiana scientific activity are: Innovative-creative direction of the world economic development as a determining component of the concept of creative economy

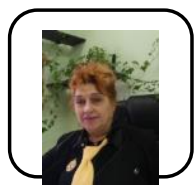

Hromozdova Larisa, $\mathrm{PhD}$ in Economics, Associate Professor, Department of Regional Studies and Tourism. Author of more than 100 scientific papers. He is currently working on his doctoral thesis on "Theoretical and Methodological Aspects of Predicting Living Standards (Regional Section)". The main areas of research are the socio-economic development of the region, the economy of enterprises.The main training courses taught by the teacher: "Regional Economics"; Recreational Complexes of the World.

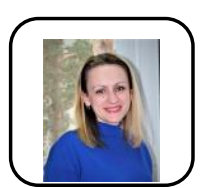

Kashina Ganna, PhD (Candidate of Pedagogical Sciences), National Pedagogical Dragomanov University. She graduated from the National Pedagogical Dragomanov University. She works in the laboratory of educational technologies. Directions of activity of Anna associate professor department of International Finance Kyiv National Economic University named after Vadym Hetman, Ukraine. Director of the Center for Management and Quality Monitoring of University Education. She graduated from the Kharkiv Engineering and Economics Institute with a major in Accounting. She defended her Doctoral dissertation on the topic: "Development of corporate strategies in the global investment environment". She delivers the following courses: "Finance multinational corporations", "Managers of International Finance", "Management of international investment projects." Scientific interests: financial globalization, corporate strategies of global investment business, finance of international corporations, international financial management, development and economic substantiation of international investment project decisions.

Kashina: development of basic, newest concepts and technologies of distance learning; study, generalization and application in the practical training of specialists of modern information and communication institutions of distance learning and creation on their basis accordingly new, advanced system of education.

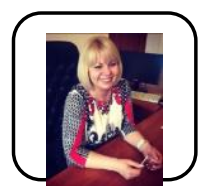
(n)

.

